Proceedings

\title{
Conurbations of the Mind: Fragmentary Photographic Narratives as a Tool for the Creation of Inclusive Urban Space ${ }^{\dagger}$
}

\author{
Dan Brackenbury ${ }^{1,2}$ \\ 1 Royal College of Art, London SW7 2EU, UK; d.r.brackenbury@leeds.ac.uk; Tel.: +44-(0)7738-461237 \\ 2 School of Design, Faculty of Arts, Humanities and Cultures, University of Leeds, Leeds LS2 9JT, UK \\ + Presented at the International and interdisciplinary conference IMMAGINI? Image and Immagination \\ between representation, communication, education and psychology, Brixen, Italy, 27-28 November 2017. \\ Published: 17 November 2017
}

\begin{abstract}
As urbanites continue to experience a broadening emotional detachment with the evolving character and identity of the urban spaces in which they live, the time has come to stop and consider our emotional connection with the built environment. By re-evaluating the subjective methods once applied in the topographic surveys of photographers such as Eugine Atget we can gain a clearer understanding of our relationship with cities. The work of such artists involves us in the imaginary and invites us to assemble our own narrative context of the landscapes which they explore. This unutilised approach reveals the perceived narrative fabric of urban space and it provokes the viewer to place their own psychological and cultural associations onto images of urbanity. I will ascertain whether such methods can be used to express the emotional connection we have to our cities, and identify how these insights can inclusively impact upon design education and the development of new urban spaces.
\end{abstract}

Keywords: built environment; architectural photography; Eugine Atget; spacial perception; imaginary cities; town planning; design education

"And I hear, from your voice, the invisible reasons which make cities live, through which perhaps, once dead, they will come to life again".

-Italo Calvino, Invisible Cities [1]

\section{Introduction}

Photography and the city have always been deeply intertwined. The city haunts photography and in turn, the medium produces uncanny depictions of urban space that haunt us. George Washington Wilson's wraithlike image of a lone boy standing in front of London's newly erected Royal Exchange in 1975 (Figure 1) poses uneasy questions about the subject. Who is this young boy and what is his relationship with the looming structures that surround him? The incorporeal incompleteness of such images engages our subconscious and we complete them in our mind, becoming thoroughly involved in their reading [2]. Montage filmmakers such as Dziga Vertov later demonstrated that in juxtaposing and sequencing similar photographic documents of urbanity, an imaginary version of the built landscape can be created, containing our own cultural and social interpretations [3].

Today, Marc Atkins's mystic Varsovian archways and Michael Wolf's abandoned vernacular furniture of Hong Kong contemplate similar questions about the people that exist within lesser documented corners of the city. Perhaps these photographs stay in the mind because of the 
incomplete stories with which they are associated. We are invited to become sutured into their narratives and adopt a perspective located within the image itself [2].

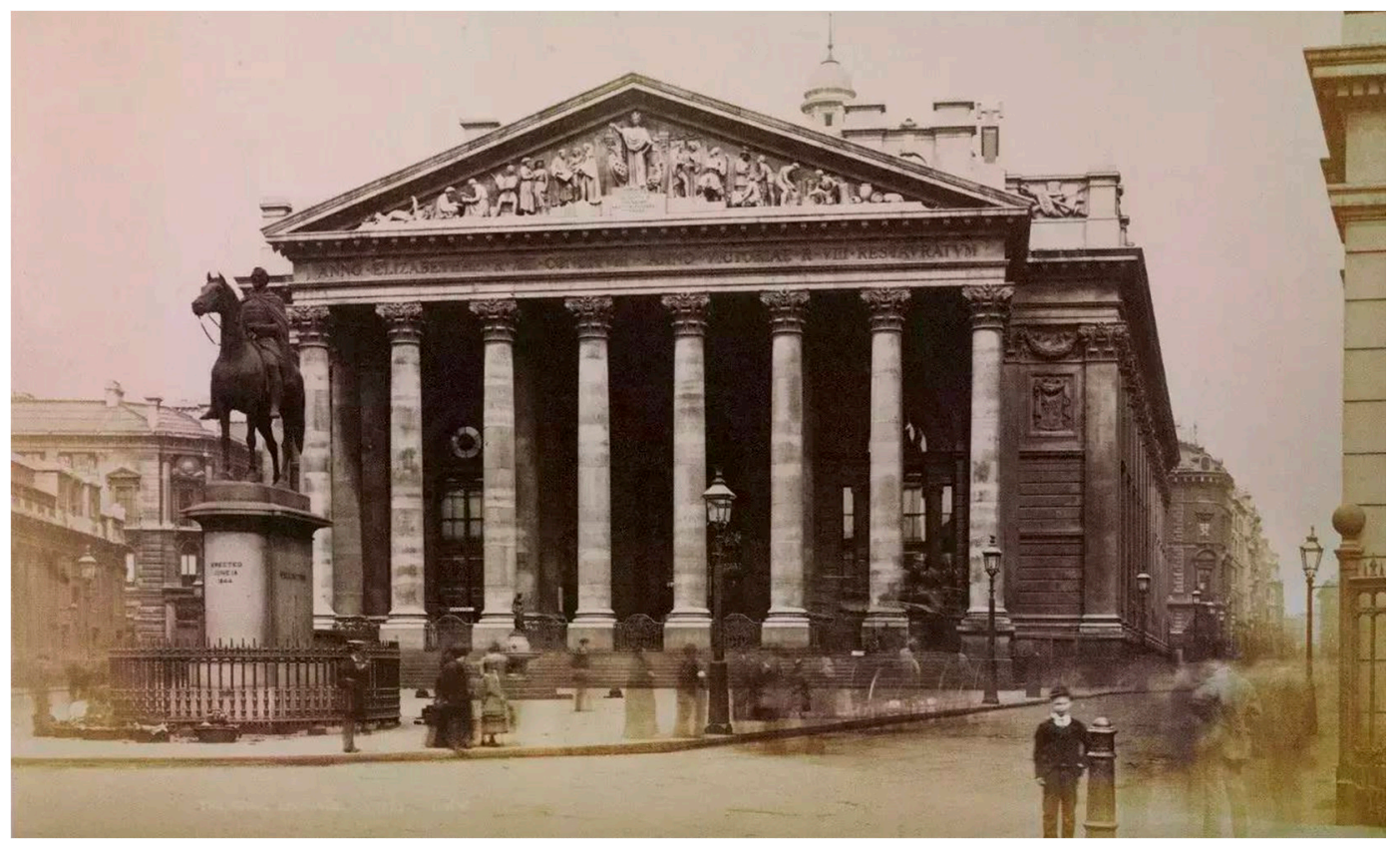

Figure 1. The Royal Exchange, large format photograph, digitally scanned, 1875 by George Washington Wilson.

If we see ourselves in certain photographs of the urban, and if they are potentially such potent and immersive storytelling devices, can they be used in the process of building cities? At a time when new developments are frequently accused of failing to achieve a distinct sense of place and respond sensitively to the surrounding environment [4] can such photographs offer an insight into the texture of the landscape of which they depict? Can they convey this sense of place and speak of how we locate ourselves within it? Contemplative photographs of built landscape have the power to envelop us in their complex, disjointed narratives [5]. I would like to ask whether such images (of which I am also an author) can thus animate the future of urbanism and be used as a tool in the planning of cityscapes.

\section{Sense of Place and Design Education}

Sense of place relates to the individual personality and character that is inherently possessed by certain landscapes. The term also refers to the relationship that people have with such spaces and the ways in which they become influenced and affected by them [6].

This concept was investigated by two distinct movements in urbanism in the 1960s. Gorden Cullen's approach placed focused primarily on the physicality of the built environment, particular architectural movements and material details within urban areas [7]. Kevin Lynch's approach was more centered around psychology and interpretation, he developed the notion of mental maps which people refer to as subconscious guides whilst navigating the city [8]. Canter felt that sense of place was achieved through a combination of these ideals along with an appreciation of the activity which happens within the city. His concept was mapped elegantly in a Ven Diagram that was subsequently reworked by two other urban theorists: Punter in 1991 [7] and Montgomery in 1998 [7] (Figure 2). The allure of sense of place has worn off in recent years but these approaches are still used to successfully to determine the principals by which effective urban areas can be created [9]. 


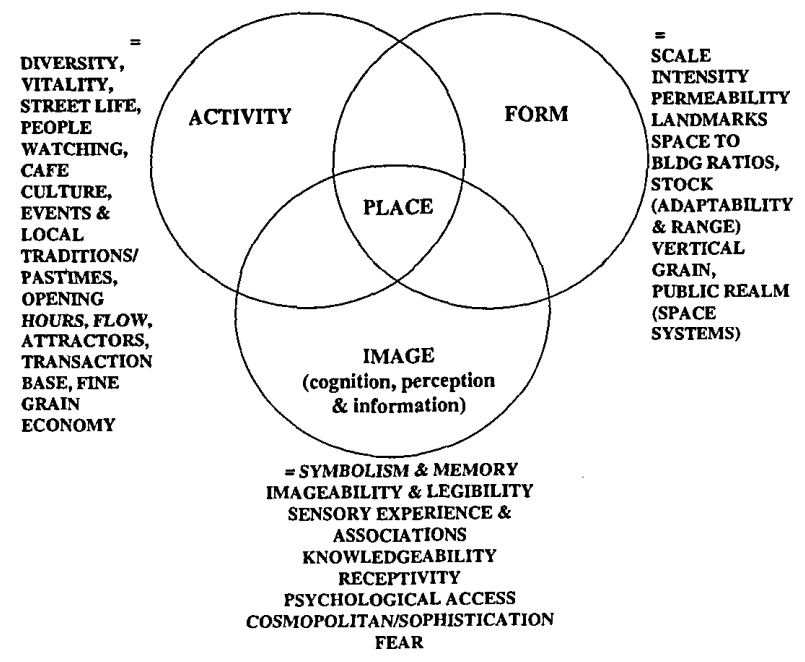

Figure 2. Montgomery's 1998 methodology for the creation of successful urban place.

Activities, form and image (cognition, perception and information) can be captured hollistically through photography in order to reveal this sense of place. Looking specifically the type of haunting [5] urban photography where narrative can be speculated upon and which Walter Benjamin described as "scene[s] of action" where "actor[s]" "uncover guilt and name the guilty" [10] (p. 25) can bring us closer to the underlying structure of the city. Through these diverse imaginary narratives, the audience forms a response to the city conditioned by their personal precepts. This process communicates a psychological understanding of how we perceive and interact with urban space [11]. While many developers now overlook the importance of storytelling in urban planning, certain fields of architecture still consider it a critical aspect of the townscape design process [12].

Benjamin's photographer as detective, like the film noir investigator, shares many of the characteristics of the flâneur. He or she applies an analytical framework for deciphering the structural and cognitive features of the built environment [13]. The practice of this type of photographer offers an as yet unultilised framework for understanding how to extract the narrative fabric of a place where urban development is proposed.

In addition to examining the validity of Montgomery's method when applied to photography, we can understand whether these findings can also be explored in a pedagogical context. As a design educator I feel that new curricula should address contemporary issues of urbanity. The demands of the industry dictate that young creatives must increasingly address the relationship that people have with their everyday environments [14]. One response to this could be to explore Atget's flâneurial approach within design education and explore ways in which such tools can be introduced to students. Methods explored by Sidaway [15] Basset [16], Krieger [17] and Gamez \& Sorensen [14] have already found potential in such concepts.

\section{The Right to the City}

Our response to new urban developments is affected more by our personal knowledge of cities than written histories, archives and documents [18]. Perhaps the above methodology for photographic urban recording can offer a more informed mechanism for citizens to voice their interpretation of the city. This process can be employed in a manner that ensures that city dwellers are better placed to influence change. Krase and Shortell have been collecting photographic snippets of urban life for several years. They explain that their archive of street photographs can be used as valuable ethnographic data which can then be utilized by architects and planners [19].

Photography has been used for such means since its inception but often in more clinical terms. Topographic records of the city were traditionally taken from an elevated perspective and focused on the material structures of buildings. This has been described as an Archimedean point of view where the empire's achievements can be appreciated [20]. Atget's topology of Paris represented a shift in perspective to one where the camera not only records the space but is integrated within it; his 
works are more focused on real and specific concerns [21]. Now planners have reverted back to a more Archimedean approach using LandSat images and aerial photographs to scrutinise landscape and urban areas before development [22]. Although regularly employed by architects such as Rem Koolhaas, these perspectives are also considered to have ideological and totalitarian associations because of their privileged capacity to scrutinize and arbitrate space [23].

Rekindling Atget's humanist methodology for urban research might allow us to return to a more emotional set of ideals. Atget's assertion that his images of Paris were mere documents [24] is often overlooked and invites re-evaluation. Perhaps the ethereal images of the city created by the photographer and his devotee Bernice Abbot, as well as more recent followers such as William Eggleston, Thomas Struth, Marc Atkins, and Michael Wolf, can help us to understand how an area's sense of place might be revealed. These photographers also create documents of urbanity and extract narratives from urban space. They see significance in the subjective, mundane and haunting oddities of the urban environment. Through their records, these disciples of Atget interrogate what it feels like to stand in a certain place at a certain time. Such photographers catch traces of Foucault's notion of spectral aura which enriches the way we perceive architecture as well as our spiritual relationship with it [5]. This imaginary offers an opportunity to consider the city in less physical and more personal, cognitive terms [25]. Therefore, I feel that a better understanding of the methods of such photographers within the context of town planning could offer exciting opportunities for urbanism and design education. In contrast to the trend for absolutist research into landscape prior to development, perhaps the impressionistic approach of the photographers above might offer a deeper understanding of how we connect subconsciously to urban environments and may point towards what Lefebrvre referred to as the urbanite's right to the city [26].

\section{Recent Case-Studies}

I have found that certain themes or textures about place become apparent to me after I apply similar investigative methodologies to my own practice. I am a lens based artist and have been concerned with how to depict the relationship between narrative and urban space for several years. In a walking journey through the fishing borough of Kennedy Town in Hong Kong I discovered that cultural divisions and the subtle boundaries between public and private spaces became far more visible under the neon illumination of the early evening. This became the basis of a body of work entitled Murmurs (Figure 3) where I recorded an internal monologue whilst trying to capture examples of urban compartmentalisation in the area.

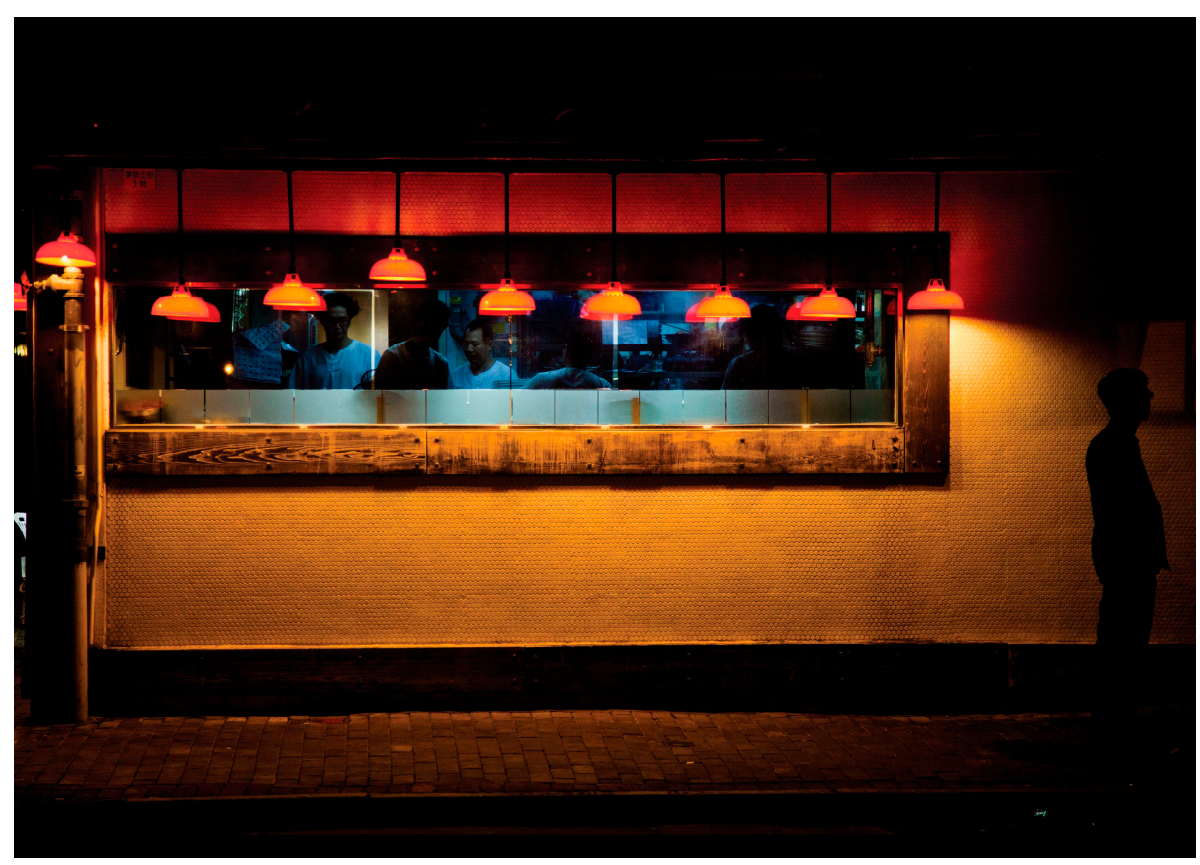

Figure 3. From the Murmurs series, digital photograph, 2011 by Dan Brackenbury. 
Within my research and teaching practice I have also explored how design students respond, through narrative and photography, to the changing nature of their urban surroundings.

Whilst teaching in Dalian, China in 2014 I developed a particular project that used photographic investigations to explore the narrative fabric of the city. Dalian is a rapidly growing coastal city in northeastern China with a population of around seven million people. It is located on the tip of the Liaodong Peninsula in the bay of Korea between the Bohai Gulf and the Yellow Sea. It is a city with a discordant history of political unrest and conflict. Its creation as an industrialised port was planned and realised by foreign powers. Once defiant emblems of Japanese colonial strength now stand as symbols of China's socialist system of government amidst the city's latest period of ultra modern urban renewal. Like many others in China, the city is constantly mutating as tapering sky-scrapers and bulbous office blocks materialise in seemingly random locations. New translucent structures take shape and blue corrugated hoardings enclose the empty spaces where old buildings once stood.

Within the heart of the city, weathering the storm of redevelopment, sits Gaoerji Lu. This once fine tree-lined boulevard appears out of place in the hectic sprawl of the downtown municipality. Set back along the street are neat domestic-scale houses with art deco features such as curved porches and bay windows. The street has a distinctly European flavour and is strangely reminiscent of a Parisian promenade.

A little more than one hundred years after the first phase of houses were completed they started to be demolished by the local government and in 2014 entire streets were starting to disappear (Figure 4). This circumstance might have arisen through a local desire to blot out the city's colonial history. The removal of the houses initiated a project to photographically document the buildings before they were lost forever. The assignment was undertaken by myself and my colleague Rob Huddleston, a fellow academic at Dalian Polytechnic University. The project was undertaken throughout 2014, initiated a critical and reflexive approach to curricular development and student learning on the BA in Graphic Arts at the University. In one particular brief, third-year students were asked to consider Susan Sontag's statement:

"The photographer-and the consumer of photographs-follows in the footsteps of the ragpicker, who was one of Baudelaire's favourite figures for the modern poet" [27] (p. 78).

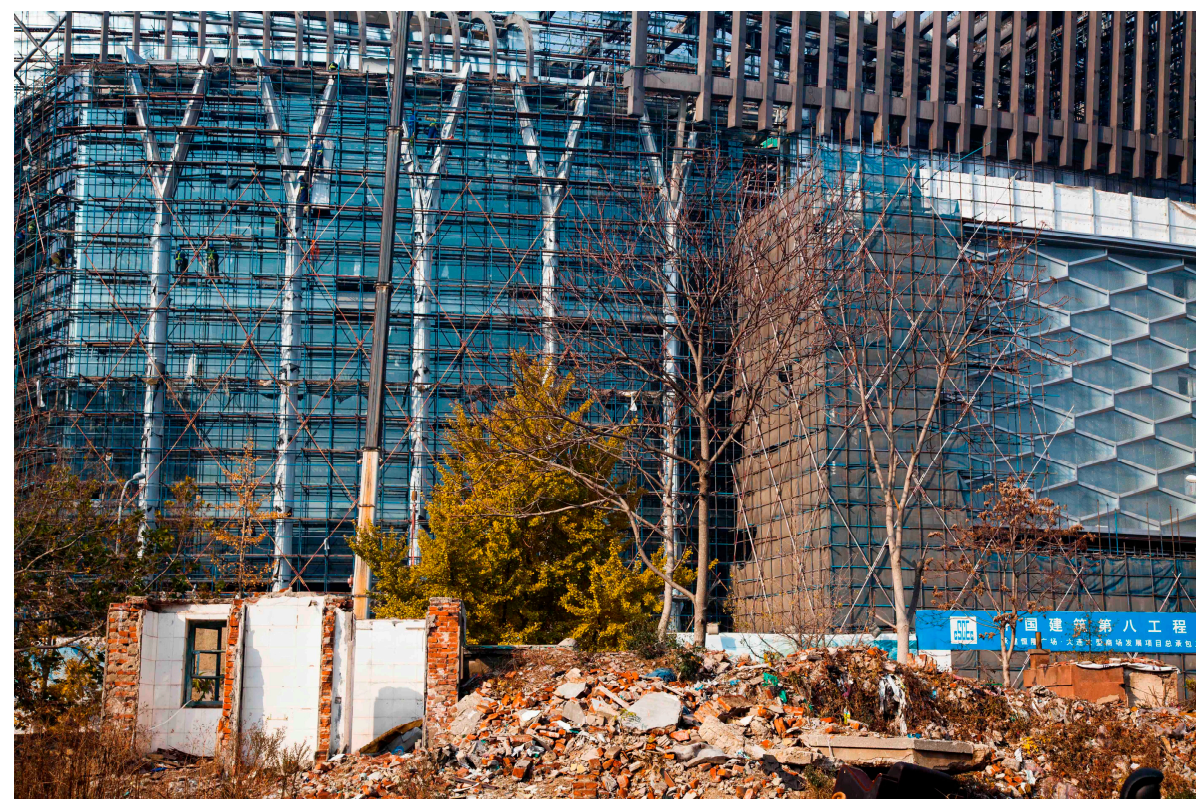

Figure 4. Fengmin Jie, digital photograph, 2014 by Dan Brackenbury.

The brief required the students to piece together scraps of stories they had encountered in their everyday lives. They then assembled their visual material into a storyboard before creating a handmade book. 
The assignment revealed much about art and design education in China as well as the personalities of the students enrolled on creative degrees here. Art in a Chinese high school involves what westerners might regard as strict training in traditional observational drawing. Chinese university regulations also require that students prove they have retained this foundation by sitting a timed exercise in the first week of their course. This focus on technique had three noticeable impacts on the students at Dalian Polytechnic University. It meant that most could make accurate observational drawings; it ensured that many were committed and methodical; but it also appeared to encourage the students to search for a different experience that would give them greater scope for creative adventure.

The handmade book seemed to offer this scope and set many of the students off on a spirited quest where they rushed to create an unexpected artefact. Some were baffled by the task but most were ready for a new experience, although they were unsure of where it might take them.

One student's response was to imagine the campus as the scene of a cryptic, unspoken crime. (Figure 5) In her book she presented photographs of deserted football pitches and refectories at nighttime with a short range flash, visualising the university as a giant film set. Another project centred in on the vast slabs of concrete that made up the majority of the college's brutalist-style 1960s structures (Figure 6). These photographs explored the way that natural light interacted with the building's harsh beige surfaces and attempted to transform the tough imposing structures into elegant, peaceful monoliths.

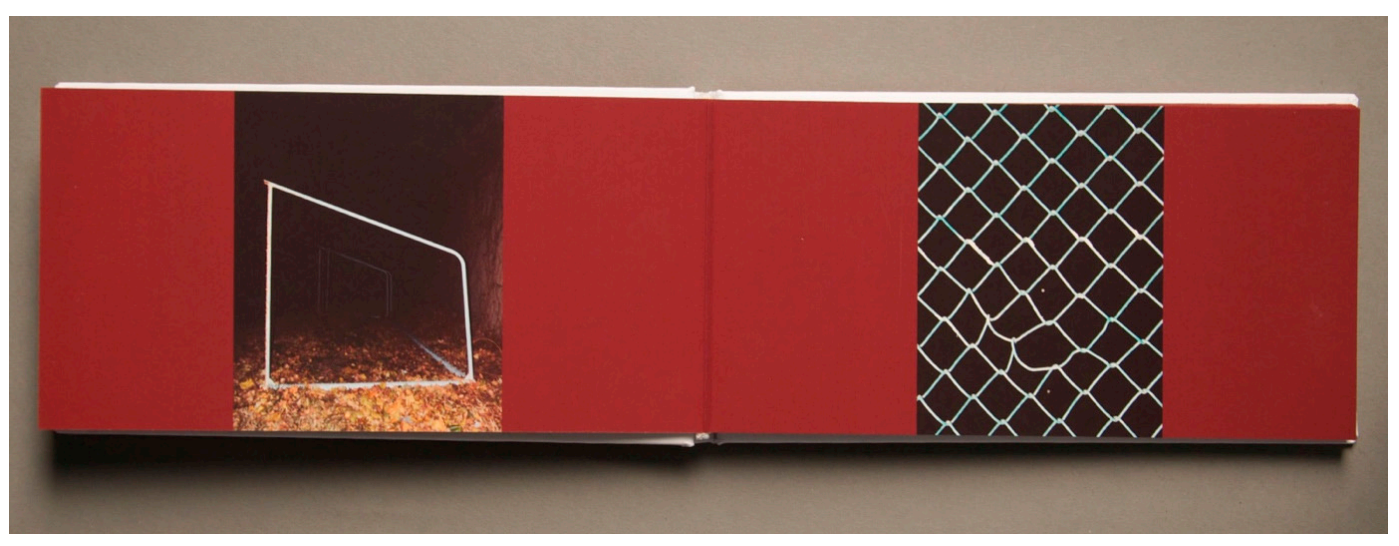

Figure 5. Spread from The Incident, hard-bound book, digitally printed, 2014 by Ding Ding.

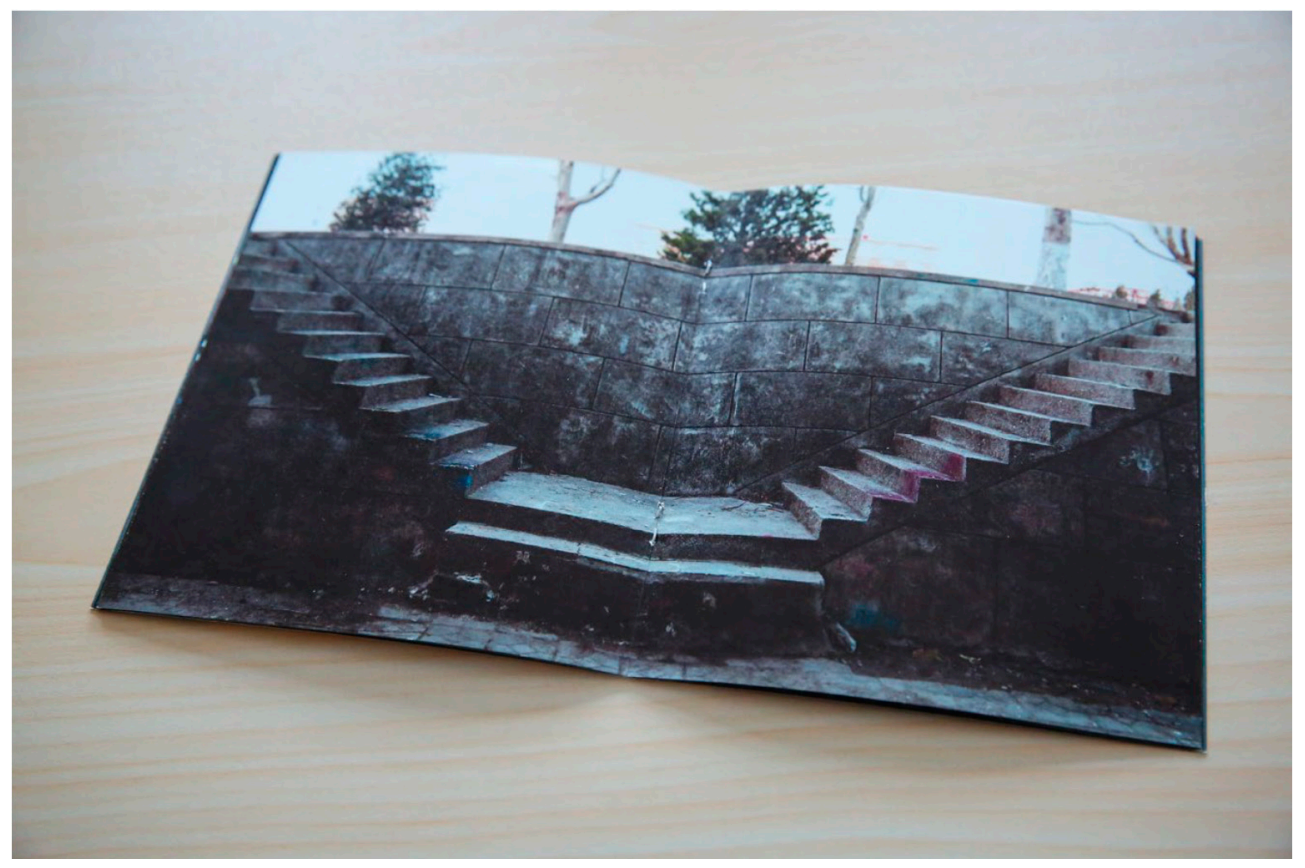

Figure 6. Spread from Concrete, soft-bound book, digitally printed, 2014 by Li Menghan. 
Studio discussions would regularly revolve around how the West viewed China and what visitors thought about certain aspects of local life in Chinese cities. Through photographing the disappearing architecture of the city a conversation was established where staff showed their insights on the adapting architectural landscape of Dalian. In return the students conveyed, through their work, how they perceived the establishment of university as well as their emotional relationship with the built environment of the city.

Later in the year a new project invited students to capture decisive moments [28] within city. They attempted to find a split second that spoke about the character of their urban surroundings. The photographs were their own interpretations of the malleable, transient nature of the metropolis. After the academic year was finished the photographs were compiled and displayed on the wall of a bookshop named Echo in the city centre. The result was an arresting study of Dalian in 2014. Abandoned objects were a common theme with subjects including broken umbrellas and discarded armchairs cast off in the road. Empty spaces figured strongly too with one image exploring the jarring contrast between a bright, sunny exterior and the dark chasm of a doorway leading inside. Another significant theme was that of children at play and caught in the fleeting moment, oblivious to anything consequential happening around them. Most of these photographs were images of serenity coupled with a sense of ambiguity; they were scenes of quietude pending disruption. The pictures also described a timeless facet of Dalian. From the Qing dynasty through to the end of the Japanese occupation and beyond, the city has either been anticipating reorder or else caught within the propulsion of hurried change.

The final project brief that year was a direct response to this ongoing dialogue between staff and students. The brief called for a short film, along the lines of a music video or title sequence. The subject had to be an architectural movement within the city and the film had to reflect its essential character. Again the responses were wide ranging but they shared important commonalities. One group looked at abandoned factory warehouses, imagining them as ghostly figures without faces. Another group examined the new tessellated architecture within the city's recent port development. They set about smashing relics of the colonial era and noted how their broken forms resembled the spikey, disjointed structures appearing on the city's coastline. An additional film focused on the European-style houses of Fengmin Jie, a photographic journey through the street was combined with a traditional Chinese folk song (Figure 7).

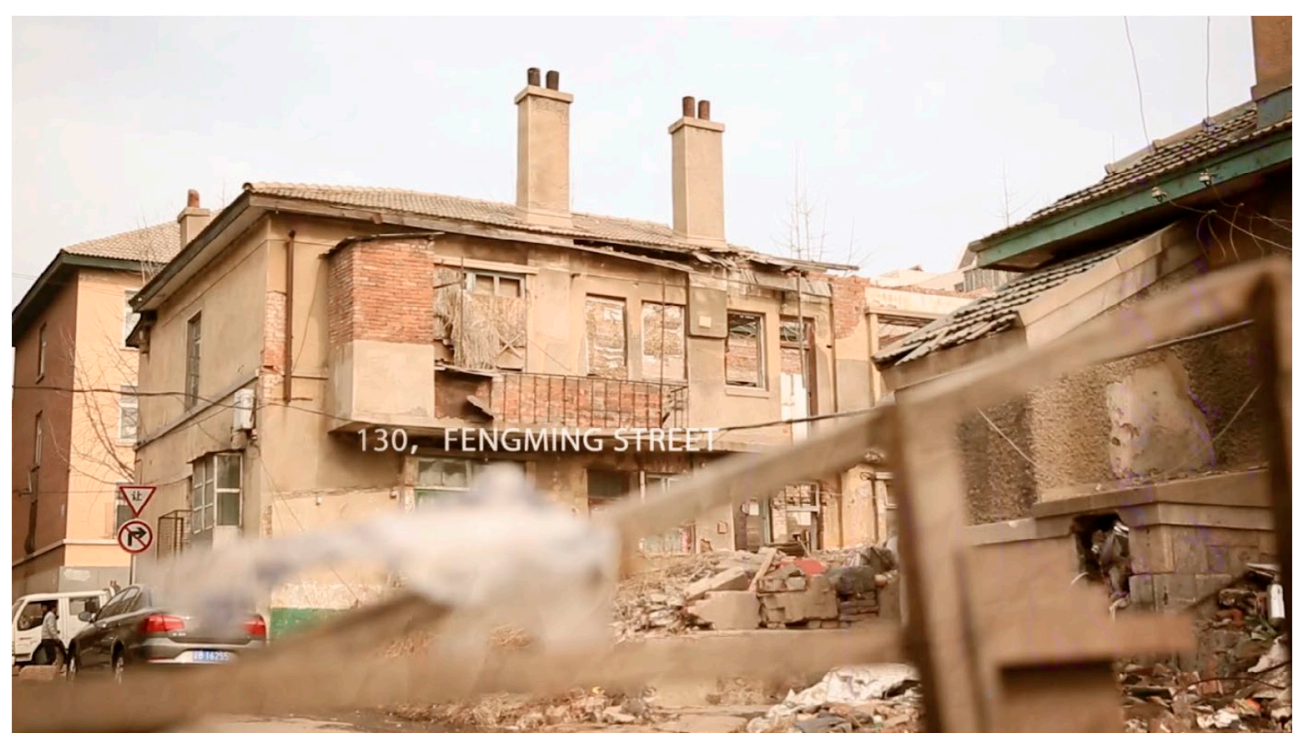

Figure 7. Still from Forgotten, digital video, 2014 by Li Menghen.

Many of the students had never edited video before but this did not prevent them from producing sequences that expressed verve and dynamic movement. On reflection this appeared to be the theme that tied each of their projects together. The students seemed to be responding to film as a medium synonymous with the transmutation of their city. At the end of the academic year staff 
evaluated each of the student projects as a single body of work. It was observed how the decisive moment photographs contemplated images of change within the city and its associated social implications. In contrast, the architectural films appeared to propose this change as reformation. In both projects students were considering how they viewed the city today. I hope to further these investigations in other cities anticipating reorder with similar design institutions in a variety of urban contexts.

Through written research and by taking on the mantle of the photographer as detective projects such as these can allow us to understand how to reveal a sense of place in a urban location facing change. We can do this by applying Montgomery's methodology within a variety of urban environments. This approach can allow us to test whether the uncanny [29] imaginary [25] and phenomenological [30] photographic methods above can communicate how the character and identity of a place can be revealed [31]. Current site research processes do not provide this type of information. Therefore, it is proposed that a more personal and reliable account of an urban area can formed through this participatory process. These narratives may provide the humanist depth that historical literature, vague community consultations and scrupulous aerial surveys lack.

What if such methods are then utilised in the early processes of townscape design? And what if these are shared and tested further with design students in cities experiencing differing stages of development? Perhaps this can open up a democratic dialogue where the role of the design educator, art photographer and town planner are blurred and where sociology takes on a practical purpose and artistic interpretation becomes functional and utilitarian [32].

\section{The Way Forward}

Bernice Abbot said that in order for photographers to capture the essence of urban modernity, photographers must first create new perspectives [33]. This notion is perhaps even more relevant today because new viewpoints on the city are urgently needed in order to understand it and respond to it. A failure to do so will likely result in a broadening detachment between the physicality of the city and the values its citizens [34].

Through a close examination of methods used by the aforementioned pioneers of the urban photograph we can gain insights into how to successfully record the unique identities and characters [35] of built environments before redevelopment. We can also begin to understand how to create new ways of looking at the city and understand its unfolding complexity. A dialogue with local town planners, community leaders, design educators and students could reflect upon the serviceability of this visual data whether it can be usefully employed in the process of planning research.

While there is much existing research around urbanism and photography, there is little discussion about how this relates in practical terms to townscape design. The products from this research will develop the relationship between these two seemingly discreet fields and create new ways to comprehend urban landscapes through photography. Indistinct, characterless space evolves into place as people explore it, come to understand it and apply meaning to it [36]. By refocusing the way that we look at spaces within the city, we can respond to the narratives of places that require our closest attention. In addition, by drawing together new associations between planners, photographers and students we can offer new, tangible and useful insights into how individuals relate to their surroundings in cities today.

The birth of photography and the beginnings of vigorous, large scale civic expansion came about at the same time, which allows for these histories to be mapped in tandem [37]. Consequently, the camera has always had a very important relationship with cityscape design in areas of rappid change. With this in mind it seems logical to turn again to areas that are being intensely urbanised [38] in order to conduct photographic investigations and test new lens-based surveying methods.

Cities such as Dalian are currently in the process of having their histories rewritten. Investigations such at those presented here can scruitinse the capacity of photography to reveal a deeper insight into the underlying narrative of urban areas. These studies can be evaluated against the views of thinkers such as Henri Lefebvre who demonstrated the ways in which cities are built upon the movement of people, their personal perspectives, representations and their relationship 
with space [39]. Within such processes the artist, planner and citizen can collaboratively record the ideals that connect us emotionally with urban space. This new type of survey could offer creative agency to stakeholders but also ensure that the autonomy of the designer is maintained. A communally inquisitive research process of this kind has potential to galvanise the creation of more egalitarian, socially inclusive cityscapes.

Acknowledgments: Thank you to Rob Huddleston of Birmingham City University, for his mentorship and guidance as well as contribution to the exercises set out in Chapter 3. Thank you also to the Graphic Arts students at Dalian Polytechnic University, particularly Wang Xue, Li Menghan, Ding Ding and Liao Jun for sharing their inspirational responses to the city.

Conflicts of Interest: The author declares no conflict of interest.

\section{References}

1. Calvino, I. Invisible Cities; Vintage: London, UK, 2002; p. 136, ISBN 0099429837.

2. Wray, T. Haunted Halls of Mirrors: Photography and the Phenomenology of Emotional Space. In Camera Constructs: Photography, Architecture and the Modern City; Higgot, A., Wray, T., Eds.; Routledge: London, UK, 2012; p. 109, ISBN 9781409421450.

3. Kear, J. In the Spiral of Time. In Phototextualities: Intersections of Photography and Narrative; University of New Mexico Press: Albuquerque, NM, USA, 2003, ISBN 0826328253.

4. Montgomery, J. Making a city: Urbanity, vitality and urban design. J. Urban Des. 1998, 3, 94, doi:10.1080/13574809808724418.

5. Wray, T. Haunted Halls of Mirrors: Photography and the Phenomenology of Emotional Space. In Camera Constructs: Photography, Architecture and the Modern City, 1st ed.; Higgot, A., Wray, T., Eds.; Routledge: London, UK, 2012, ISBN 9781409421450.

6. Malpas, J. New Media, Cultural Heritage and the Sense of Place: Mapping the Conceptual Ground. Int. J. Heritage Stud. 2008, 14, 201, doi:10.1080/13527250801953652.

7. Montgomery, J. Making a city: Urbanity, vitality and urban design. J. Urban Des. 1998, 3, 95, doi:10.1080/13574809808724418.

8. Montgomery, J. Making a city: Urbanity, vitality and urban design. J. Urban Des. 1998, 3, 95, doi:10.1080/13574809808724418. p. 101.

9. Montgomery, J. Making a city: Urbanity, vitality and urban design. J. Urban Des. 1998, 3, 95, doi:10.1080/13574809808724418 p. 97.

10. Montgomery, J. Making a city: Urbanity, vitality and urban design. J. Urban Des. 1998, 3, 95, doi:10.1080/13574809808724418

11. Highmore, B. Cityscapes, 1st ed.; Palgrave Macmillan: Basingstoke, UK, 2005, ISBN 0333929357.

12. Childs, M. Storytelling and urban design. J. Urban. Int. Res. Placemak. Urban Sustain. 2008, 1, 184, doi:10.1080/17549170802221526.

13. Jenks, C.; Neves, T. A walk on the wild side: Urban ethnography meets the Flâneur. Cult. Values 2000, 4, 184, doi:10.1080/14797580009367183.

14. Gamez, J.; Sorensen, J. No more waiting for Superman: Teaching DIY urbanism and reflexive practice. J. Urban. Int. Res. Placemak. Urban Sustain. 2014, 7, 384, doi:10.1080/17549175.2014.909516.

15. Sidaway, J. Photography as Geographical Fieldwork. J. Geogr. High. Educ. 2002, 26, 95-103, doi:10.1080/03098260120110395.

16. Basset, K. Walking as an Aesthetic Practice and a Critical Tool: Some Psychogeographic Experiments. J. Geogr. High. Educ. 2004, 28, 397-410, doi:10.1080/0309826042000286965.

17. Krieger, M. Taking Pictures in the City. J. Plan. Educ. Res. 2004, 24, 213-215, doi:10.1177/0739456X04271625.

18. Lisiak, A. Making sense of absence. City 2015, 19, 848, doi:10.1080/13604813.2015.1090186.

19. Krase, J.; Shortell, T. On the Spatial Semiotics of Vernacular Landscapes in Global Cities. Vis. Commun. 2011, 10, 371, doi:10.1177/1470357211408821.

20. Whittaker, E. Photography and the Subject of Architecture. In Camera Constructs: Photography, Architecture and the Modern City, 1st ed.; Higgot, A., Wray, T., Eds.; Routledge: London, UK, 2012, ISBN 9781409421450.

21. Ibid. 
22. Zhang, Y.; Guindon, B.; Sun, K. Spatial-temporal-thematic assimilation of Landsat-based and archived historical information for measuring urbanization processes. J. Land Use Sci. 2015, 10, 369-387, doi:10.1080/1747423X.2014.93972.

23. Last, N. Reimag(in)ing the Urban. Vis. Resour. 2010, 26, doi:10.1080/01973760903537892.

24. Atget, E.; Andreas, K.; Adam, H. Eugène Atget's Paris; Taschen: Köln, Germany, 2001, ISBN 3836504715.

25. Paeslack, M. High-Speed Ruins: Rubble Photography in Berlin, 1871-1914. Future Anterior J. Historic Preserv. Hist. Theory Crit. 2013, 10, 33, doi:10.1353/fta.2013.0018.

26. Lefebvre, H.; Kofman, E.; Lebas, E. Writings on Cities; Blackwell Publishers: Cambridge, MA, USA, 1996, ISBN 0631191887.

27. Sontag, S. On Photography; Pegnuin: London, UK, 2002; p. 78, ISBN 0312420099.

28. Cartier-Bresson, H. The Decisive Moment; Steidl: Göttingen, Germany, 2015, ISBN 3869307889.

29. Rosengarten, R. Constructing Worlds: Photography and Architecture in the Modern Age. Photogr. Cult. 2015, 8, 365, doi:10.1080/17514517.2015.1091185.

30. Jenks, C.; Neves, T. A walk on the wild side: Urban ethnography meets the Flâneur. Cult. Values 2000, 4, 1, doi:10.1080/14797580009367183.

31. Magee, C. There Is a There There: Place in African Cityscapes. Photogr. Cult. 2014, 7, 60, doi:10.2752/175145214X13936100122327.

32. Kramer, K.; Short, J.R. Flânerie and the globalizing city. City 2011, 15, 322-342, doi:10.1080/13604813.2011.595100.

33. Paeslack, M. High-Speed Ruins: Rubble Photography in Berlin, 1871-1914. Future Anterior J. Historic Preserv. Hist. Theory Crit. 2013, 10, doi:10.1353/fta.2013.0018.

34. Malpas, J. New Media, Cultural Heritage and the Sense of Place: Mapping the Conceptual Ground. Int. J. Heritage Stud. 2008, 14, 197, doi:10.1080/13527250801953652.

35. Ibid p. 201.

36. Tuan, Y. Space and Place; University of Minnesota Press: Minneapolis, MN, USA, 2001; p. 6, ISBN B00JIAYEN2.

37. Krieger, M. Taking Pictures in the City. J. Plan. Educ. Res. 2004, 24, 215, doi:10.1177/0739456X04271625.

38. Kramer, K.; Short, J.R. Flânerie and the globalizing city. City 2011, 15, 338, doi:10.1080/13604813.2011.595100.

39. Paeslack, M. High-Speed Ruins: Rubble Photography in Berlin, 1871-1914. Future Anterior J. Historic Preserv. Hist. Theory Crit. 2013, 10, 34, doi:10.1353/fta.2013.0018.

(C) 2017 by the author. Licensee MDPI, Basel, Switzerland. This article is an open access article distributed under the terms and conditions of the Creative Commons Attribution (CC BY) license (http://creativecommons.org/licenses/by/4.0/). 